\title{
The Way of the Social and Economic Development of
}

\section{China-An Attempt of Historical and Synthetic Representation}

\author{
Barbara Siuta-Tokarska \\ Cracow University of Economics, Cracow, Poland
}

\begin{abstract}
The issue of social and economic development is an important part of theoretical and empirical research of the contemporary economy. China is an example of an economy which in a short period of time achieved success within this scope. Therefore it seems to be justified to draw the reader's attention to the factors and determinants which may be regarded as the key ones for the economy of China, both in the period of 1949-1978, namely, in the period of real socialism, and in the period after 1978, so-called "socialist market economy" to date. On the basis of an analysis of Polish and foreign reference sources and source materials, the author tried to trace both similarities and differences in China's economic development over those two periods, first of all paying attention to the Chinese authorities' pragmatism of governing in the other period, accompanied by limiting ideological influences. Maintaining the socialist system, in that period China worked out its own, specific principles, and rules of internal activities and activities in the international arena, which enabled to it the creation of a model, especially for developing countries, the system of economic planning and programming, its constant modernization during the implementation of economic tasks, with the consideration given to changing conditionings in the world economy. It was pointed out that with maintaining the laboriousness of the Chinese and their loyalty to authority, they make up China's economic power. The aim of the article is to pay special attention to the circumstances, phenomena, conditionings, and factors which occurred on the way to the social and economic development of China, which enabled it to achieve the economic success in a relatively short period of time. This success can be expressed by such indicators as for instance the poverty rate, the unemployment rate, gross domestic product, the value of export, and the value of foreign direct investment as well as other factors.
\end{abstract}

Keywords: social and economic development, economy of China, real socialism, socialist market economy

\section{Introduction}

In the contemporary world economy, China is an important player, competing for "the palm" with the United States of America, as well as with other leading economies of the world. The present position of China in the global economy is an effect of numerous factors, processes, and changes made both in the Chinese economy itself and the changes accomplished in its environment, namely, in the world economy.

A lot of economists point to the success of the Chinese economy (UNCTAD, 2005) whose roots can be traced back to a few dozen years ago, from the date of proclaiming the People's Republic of China in 1949 and

Barbara Siuta-Tokarska, Ph.D., Department of Economics and Enterprise Organization, Cracow University of Economics.

Correspondence concerning this article should be addressed to Barbara Siuta-Tokarska, Department of Economics and Enterprise Organization, Cracow University of Economics, Rakowicka 27, 31-510 Cracow, Poland. E-mail: siutab@uek.krakow.pl. 
implementing the policy of reforms in it in 1978, related to opening its borders. Over the last 30 years, the economy of China has become the fastest developing economy of the world (Liberska, 2010).

The People's Republic of China is a state of the area of 9,562 thousand $\mathrm{km}^{2}$ which makes it the third biggest state in the world with regard to the area, following Russia and Canada, with the population of 1,344 billion (according to the data from the World Bank for 2011), constituting around 21\% of the world's population. It is situated in Central and East Asia, and the length of its land border is $22,800 \mathrm{~km}$, and of the continental sea border-18 thousand km. Over 5,400 coastal islands belong to China. The administrative division of the state includes: 22 provinces, five autonomic regions, two special administrative regions, namely, Hong-Kong and Macau, as well as four separated cities ("China”, 2001).

China is the state of real socialism, according to the constitution enacted in December 1982 and binding to date, although at present it does not have one of the basic canons of the socialist economy which is social entity and the prevalence of the public sector, by legitimating an increase in the role of the private sector in economy (Góralczyk, 2012a). As early as in 1984, China used the notion of "socialism with Chinese characteristics" which three years later was converted into an official programme and the state policy alongside the simultaneous opening up to the world and cooperation (Góralczyk, 2012b).

What proves the development and the power of the Chinese economy in the contemporary world is, in particular, an annual increase in GDP over the last 30 years of about $10 \%$ on average (World Bank, 2013), and a significant growth of GDP per capita (Flassbeck, Dullien, \& Geiger, 2005), a leading position in the world exports and in currency reserves, a considerably low level of unemployment ${ }^{1}$, or the fact of leading about 400-500 million people out of poverty over the last three decades ${ }^{2}$. In spite of the global economic crisis, the Chinese economy still is and, in the coming years, will be one of the major, if not the major actor in creating changes in the world economy (Garnaut, Song, \& Woo, 2009; Dahlman, 2010; Fu, 2012).

\section{The Proclamation of the People's Republic of China and the Direction of Economic Changes in the Years 1949-1978}

For the proper assessment of the economic position of China, it is worth paying attention to the chronological review of selected events in the years 1949-1978. Table 1 lists data within this scope.

To illustrate the way of the social and economic development of China starts with the years 1949-1978, it seems justified to make an "overview" of the situation in the preceding period, as a starting period for the introduced changes, namely, at least since the first half of the 20th century.

At that time, China was an underdeveloped country in the world economy. The base of the economy was a semi-feudal agriculture based on the labour of petty peasants-tenants, which did not even meet the needs of the growing population. Industrial production occupied a "modest position" in the economy, and it was implemented in small plants, with obsolete devices and technical equipment (Brandt, 1997). A little bit more modern areas of industry were situated in the north-eastern China and usually in the hands of foreign capital, or

\footnotetext{
${ }^{1}$ According to the data of the World Bank for 2011, the unemployment rate in China, calculated as the percent of total labour force was $4.1 \%$.

${ }^{2}$ The poverty rate in rural China fell from $18.5 \%$ in 1981 to $2.8 \%$ in 2004 (from 152 million people to 26 million). Measured in terms of the World Bank Poverty Standard - China's poverty reduction has been more striking. The fraction of the population consuming below this poverty line fell from $65 \%$ in 1981 to $10 \%$ in 2004 (the number of the poor fell from 652 million to 135 million). Measured by the international poverty standard of 1.25 USD per person per day (Purchasing Power Parity for China 2005), the levels of poverty fell from $85 \%$ in 1981 to $27 \%$ in 2004 (China from Poor Areas, 2009).
} 
under control of a small group of so-called "comprador bourgeoisie". Apart from some mining centres and dispersed industry, the population was employed in activity related to craft (“China”, 2001).

Table 1

The Chronological Review of Selected Important Events in China in the Years 1949-1978

\begin{tabular}{|c|c|c|}
\hline No. & Year/Years & Kind of events \\
\hline 1 & 1949 & $\begin{array}{l}\text { Proclaiming the People's Republic of China on } 1 \text { October, 1949. The government of the Republic of China } \\
\text { under the leadership of Chiang Kai-Shek found shelter in Taiwan in December } 1949 .\end{array}$ \\
\hline 2 & $1950-1953$ & War in Korea, the beginning of the confrontation between US and the People's Republic of China. \\
\hline 3 & 1956 & The Hundred Flowers policy, temporary liberalization of the system. \\
\hline 4 & $1958-1960$ & $\begin{array}{l}\text { Mao Zedong pushes so-called "The Great Leap Forward", people's communes and barracks communism. A } \\
\text { lot of provinces famine-stricken. }\end{array}$ \\
\hline 5 & $1960-1965$ & $\begin{array}{l}\text { The period called intervening years: Mao Zedong is removed from "theoretical work", and the real power is } \\
\text { in the hands of pragmatists (President Liu Shaoqi, Premier Zhou Enlai and the real leader of the Communist } \\
\text { Party of China-Deng Xiaoping). }\end{array}$ \\
\hline 6 & $1966-1976$ & Cultural revolution-Mao Zedong regains and keeps power for many years. \\
\hline 7 & 1971 & The beginning of the normalization of relations with US. China "regains" its seat in UN. \\
\hline 8 & 1972 & The visit of US President, Richard Nixon in the People's Republic of China. \\
\hline 9 & 1975 & $\begin{array}{l}\text { An attempt to order the state affairs: so-called "the Four Modernizations" undertaken by Premier } \\
\text { Zhou Enlai with the help of Deng Xiaoping. }\end{array}$ \\
\hline 10 & 1976 & $\begin{array}{l}\text { Death of Zhou Enlai. First trials against Maoist extremists. On All Saints' Day, 4-5 April, 1976, million } \\
\text { demonstrations on the Tiananmen Square in honour of Zhou Enlai, suppressed by the authorities. Deng } \\
\text { Xiaoping was under house arrest. The death of Mao Zedong on } 9 \text { October, 1976. After his funeral, the } \\
\text { people from so-called "Gang of Four" were arrested. }\end{array}$ \\
\hline 11 & 1977 & $\begin{array}{l}\text { Full rehabilitation of Deng Xiaoping during the third Plenum of the Central Committee of the Communist } \\
\text { Party of China on 16-21 July, 1977, and his return to power. }\end{array}$ \\
\hline
\end{tabular}

Out of more significant events in the first half of 20th century, we should indicate (The Modern China, 2012):

- The beginning of the collapse of the state in 1916 after the former Empire;

- The formation of the Communist Party of China in 1921 and the consolidation of the state under the leadership of Kuomintang;

- Seizing Manchuria by Japan and creating a "puppet state" there, as well as creating the Chinese Soviet Republic by Mao Zedong in Jiangxi in 1931;

- Japan's invasion on China and the war of resistance made by a nominally joint front of the Communist Party of China and Kuomintang in the years 1937-1945;

- Civil war of the Communist Party of China and Kuomintang in the years 1947-1949.

The mentioned war events devastated the country and its economy which required fast reconstruction. It was completed in the years 1949-1952 (Shen, 2000) after several years of wars and even a longer period of chaos, anarchy, and dominance of various foreign powers. The state administration and the system of education were reconstructed, cities and streets were tidied up, dams and irrigation channels were repaired (China Committee for the Promotion of International Trade, 1952). Moreover, banditry, criminal delinquency, drug addiction, and prostitution were combated, and there was an attempt to restore moral principles. An agricultural reform was done, which assured quite common support in the countryside for the new authorities because it introduced the equality of citizens, also women. A considerable improvement of the conditions of living in cities was achieved ("China", 2001).

In the following years, 1953-1957, the economy was modernized in the Soviet fashion. The first five-year 
plan of the socialist type economy development was drawn up, putting emphasis on the development of heavy industry and the development of agricultural production. In villages it was "ordered" to establish farming cooperatives, and in craft and trade cities private enterprises were transformed into private-state companies employing their former owners as specialists and sharing profits with them. On the other hand, there was an attempt to limit controversial transformations by the extension of party organizations and political and ideological propaganda (Gawlikowski, 2012a).

After Stalin's death and the criticism of the cult of personality, Mao Zedong, assuming that Soviet models cannot be imitated directly, in May 1956 initiated a campaign called: "let a hundred flowers bloom and a hundred schools of thought compete", acting as a spokesman of the democratization of life and admitting various views. In September 1956, at the Convened 8th Congress of the Communist Party of China, under an influence of the critique of accelerating socialist transformations, Mao Zedong withdrew from the everyday ruling of the state to the benefit of "collective management" (Gawlikowski, 2012a). One year later, due to the critique of the Communist Party of China, The "Hundred Flowers Movement" was ended, and Mao Zedong and his supporters regained power and started to push so-called "The Great Leap", people's communes and the new line of the party, by giant mobilization of the society wanting to bring to a considerable economic growth. The implementation of this policy, and first of all the strive at obtaining a significant increment of production of steel in primitive conditions, could not bring expected benefits, but only rapid worsening of the economic situation of China ("China”, 2001).

A difficult situation in the country forced the leaders of the Communist Party of China to revise the conducted economic policy, and in 1961 the policy of so-called "intervening" was adopted, considering economic mechanisms. A political split into two factions took place, so-called "pragmatic faction" and "the faction of Mao Zedong's supporters". A few years later, there was so-called "Cultural Revolution" in China, proclaimed by Mao's supporters. Its aim was to break the party and the state apparatus and replacing it with a new and more revolutionary one. Those events were taking place in the years 1966-1976, but the policy of "intervening" was condemned as the restoration of capitalism".

In 1976, alongside Mao Zedong's death (September 1976), the death of many year's leader of the People's Republic of China and the leader of the Communist Party of China, and alongside the death of Zhou Enlai (January 1976), a many year's Premier of the state, the era of the government of the two very important leaders of China ended (Kampen, 2000).

Positive changes in China's economic development occurred after the "Cultural Revolution" was over, but social and economic problems were solved slowly and with not too effective administration and command methods ("China", 2001).

After Mao's death, moderate Maoists, supported by some old communists, made a military coup and arrested the governing radicals. Deng Xiaoping was invited to govern the country (Gawlikowski, 2012b).

It is worth emphasizing that due to the changes made in the Chinese economy in the years 1949-1978, in spite of the mistakes made and failures in planning the economy, also successes were achieved (Dollar, 1988), and as early as in the years 1975-1982 the annual average GDP growth rate was 6.0\% ("China", 2001). In 1949

\footnotetext{
3 During the Cultural Revolution, the power in China was taken over by a small group of people concentrated around Mao Zedong, power in the regions was seized by the army, the regional party apparatus was scattered. In the revolutionary chaos, the industrial production decreased. After 1971, Premier Zhou Enlai made an attempt of a partial resignation from the goals of the cultural revolution.
} 
China had the population of 541.6 million and since then there was a "quick" increase in the population, with an exception of the collapse period in the years 1959-1961 due to the famine evoked by the mistakes of "The Great Leap" (in those years the birthrate was negative) ("China", 2001). In the years 1976-1979, the population of China was estimated to about 926 million.

China is one of the richest countries in the world with regard to mineral resources. In 1978, it was at the third place in the world in coal extraction. In the 1960s new deposits were discovered and oil extraction was realized. Moreover, China extracted oil shale, iron ores, tungsten ores (the first place in the world in 1977), antimony, lead, copper ores, manganese, molybdenum, mercury, bauxite, kaolin tins, and rock phosphate. The production of electrical power in 1978 was 256.5 billion $\mathrm{kWh}$. The processing industry was concentrated mainly in the north-eastern and eastern part of the country. The textile industry was best developed and so was the iron and non-ferrous metal industry, mechanical engineering, cement, leather, food, timber industry, and generally craft. Moreover, there was the development of agriculture within the scope of mechanization, the extension of the system of artificial irrigation and chemical fertilizer application. In those years China maintained trade contacts with numerous countries, such as Japan, Hong Kong, Federal Republic of Germany, France, Canada, United Kingdom, Malaysia, USA, or Australia ("China", 1983).

The activities undertaken by China in the years 1949-1978 in the social and economic area indicate a considerably big economic potential of the state. We may think that, among others, the potential mostly came from:

- Toughness and experiences of the Chinese, gained during the revolutionary changes, used at work and in everyday life in hard economic conditions;

- The mobilization of the citizens and their involvement in taking and implementing necessary economic ventures, which resulted, among others, from their objectification by the state authorities;

- "Culture and ethos" of labour, prudence and obedience to authority;

- Constant search for a "proper" way of the social and economic development of China by the state government.

\section{A Chosen and Implemented Way of China's Social and Economic Development Over the Last 30 Years}

After the era of Mao Zedong and Zhou Enlai's reign in China, at the beginning of the 1980s, a big breakthrough took place, aiming at the radical transformation of economy. Under many years' leadership of Deng Xiaoping and after the rejection of the ideology of doctrinarism, China entered the way of economic pragmatism, opening up to the world and proceeding towards "the market economy". In the country traditional family farms revived. It was permitted to establish private enterprises, and companies created by public entities were conducting activity according to market principles. Special economic zones were appointed, in which favourable conditions for foreign investors were created, and new methods of managing were "tried out". Foreign capital was used mainly to implement direct investment or it was made up by foreign loans of the state (“China”, 2001).

Over the last 30 years, foreign capital has been involved in various forms, but the majority was invested in special economic zones, such as Shenzhen, Shantou, Zhuhai, Xiamen, or Hainan, in the so-called open coast cities and special zones of economic development in other big cities. Moreover, more and more of the Chinese capital is invested abroad. As early as in 1997, over 5,350 enterprises located in 140 countries of the world 
constituted the property or co-property of the Chinese capital ("China", 2001).

On the one hand, China is one of the most important recipients of Foreign Direct Investment (FDI) because the value of the accumulated FDI in 2011 was 736 billion USD, giving it the seventh position among the countries of the world, and on the other hand, it invests abroad itself (the value of the accumulated Chinese FDI in 2011 was 322 billion USD). It is estimated that the number of the established companies with the Chinese capital is 18 thousand in 178 countries of the world, and the value of their assets is about 1.6 trillion USD (Oziewicz, 2012).

Pragmatism and rationality in proceedings and opening up to foreign investment, controlled by the authorities and properly directed, bore fruit to China in the introduction of "leading technical studies and modern technologies". To a great extent, it is related to the presence of 490 out of 500 biggest transnational corporations in China, which enables China not only to export labour-consuming and technologically low-processed goods, but also to export goods included in the medium and high technique. Today, numerous sectors of the Chinese industry are making the world's shortlist, e.g., the automotive industry with the production of passenger cars and buses. One of the firms of this sector is a 20-year-old King Long corporation manufacturing buses, the third biggest enterprise in the world, mainly selling to the Chinese market, but also to 50 countries of the world (Oziewicz, 2012).

Chinese FDI is focused, among others, on (Szumski, 2012):

- Obtaining access to state-of-art technologies and modern techniques of the organization of work;

- Purchase or lease of farmland, especially in Africa and Latin America;

- Purchase of shares of "huge companies" with famous brands, not only in the automotive industry but also in the electronic industry, and others;

- Ensuring access to raw materials, including the search for new sources.

The majority of the Chinese FDI was initially located in Asia and Africa, but now their increase by 20\%-30\% a year has also taken place in US, Latin America countries, the European Union, or Japan (Szumski, 2012).

In the economic development of China foreign trade played an extremely important role, especially after China's accession to the World Trade Organization (WTO) in 2000 and accepting the regulations of the International Monetary Fund.

From the beginning, reformers in China made an assumption that, contrary to the opinions of the free trade theory supporters, not the complete but the gradual and the state-controlled opening of the economy will enable to include China in the globalization processes. A similar strategy was already successfully implemented in Singapore and Malaysia (Oziewicz, 2012).

At present, China is the "biggest" exporter in the world, and the main recipients of the Chinese exports is US, Hong Kong (being, among others, a re-exporter of Chinese goods), and Japan. At the same time, China is the second world importer, following US, and the main partners are: Japan, South Korea, and US (Oziewicz, 2012).

While maintaining the leadership of the communist party and transforming from the real socialism phase to the phase of the "socialist market economy" in 1992, China strengthens "market tendencies" in the economy. It is worth stressing that the reforms and the modernization of the economic system were accompanied by the proper use of many various conditionings of the economic growth, such as (Lisbonne-de Vergeron, 2012):

- The biggest population in the world; 
- Considerable economic autarchy, ensuring the resources of cheap workforce;

- "Large" natural resources, expressing, among others, by: one third of the global coal extraction, one third of cement production, one-fourth of sulfuric acid production, or $13 \%$ share in the global production of steel;

- Technical and technological progress in industry, including electronics and materials engineering, which foreign investment favours;

- Allocation of workforce from agriculture to industry and services, especially to regions with high economic growth;

- Expansion in export activity;

- The growth of the dynamics and the value of the FDI implemented in China since 1986, namely, since the abolishing limitations for foreign investment;

- Administrative incorporation of Hong Kong and Macau to China, and maintaining their political autonomy.

On the other hand, the weaknesses and threats for further fast economic development of China include, among others (Szpak, 2007):

- A decrease in the area of farmland, as a result of ecological damages and erosion;

- Disproportions in the territorial development: strong economically developed eastern regions and poorly developed other regions;

- Intensification of conflict between "poor country and enriching city";

- Shortages of electric power for industry;

- Aging society, related to the "one child policy";

- The occurrence of the phenomena of bureaucracy and corruption.

To these weaknesses we can add degradation of the environment, related to too intensive growth of industry and urban economy.

China's economic development, also in the first years of the global economic crisis may be proven by selected indicators referring to the issue of development, presented in Table 2.

Table 2

Selected Indicators and Economic Data of the Chinese Economy in the Years 1980-2009

\begin{tabular}{lclll}
\hline Year & Growth of GDP (\%) & $\begin{array}{l}\text { Value of the exports of goods } \\
\text { (in million USD, current prices) }\end{array}$ & Inflow of FDI (dynamics in \%) Currency reserves \\
\hline 1980 & 7.8 & 18,099 & 57 & 2 \\
1995 & 10.9 & $148,780[100.00]$ & $37,521[100.00]$ & $74[100.00]$ \\
2000 & 8.4 & $249,203[167.50]$ & $40,715[108.51]$ & $166[224.32]$ \\
2001 & 8.3 & $266,098[106.78]$ & $46,878[115.14]$ & $212[127.71]$ \\
2002 & 9.1 & $325,596[122.36]$ & $52,743[112.51]$ & $286[134.91]$ \\
2003 & 10.0 & $438,228[134.59]$ & $53,505[101.44]$ & $404[141.26]$ \\
2004 & 10.1 & $593,326[135.39]$ & $60,630[113.32]$ & $610[150.99]$ \\
2005 & 10.4 & $761,953[128.42]$ & $72,406[119.42]$ & $819[134.26]$ \\
2006 & 11.6 & $968,936[127.16]$ & $72,715[100.43]$ & $1,066[130.16]$ \\
2007 & 13.0 & $1,217,939[125.70]$ & $83,521[114.86]$ & $1,528[143.34]$ \\
2008 & 9.0 & $1,428,500[117.29]$ & $108,312[129.68]$ & $1,966[128.66]$ \\
2009 & 8.7 & $1,330,600[93.15]$ & $95,000[87.71]$ & $2,545[129.45]$ \\
\hline
\end{tabular}

From the analysis of the data in Table 2 we can observe that within 10 years (2000-2009) the exports of 
goods increased over five times, the inflow of FDI went up over 2.3 times and the currency reserves grew over 15 times with the growth of GDP staying at about $10 \%$ on average. It undoubtedly proves a great mobility of the Chinese economy and good bases within the scope of the prospects for it further development (Fung \& Peng, 2012). Even during the global economic crisis, the Chinese used opportunities for the expansion of Chinese enterprises to overseas markets, among others by taking advantage of a drop in the prices of the assets of many companies and buying them out, with a lot of help from the state in raising credits for mergers and takeovers to build the global position of Chinese business entities (Liberska, 2010). Moreover, supporting the actions of the International Monetary Fund on giving assistance to countries in the crisis, China bought foreign bonds for 50 billion USD and established bilateral currency swaps for 95 billion USD (Liberska, 2010). China is an important economy in the International Monetary Fund, which is related to its significant influence on the Fund's decisions and partially also on the directions of the world economy development (Grotte \& Życieńska, 2011).

As the research by the American Pew Research Center from 2007 and 2010, in spite of numerous social and economic problems in China, occurring due to the dynamically developing economy and a great volatility of external conditionings, the Chinese citizens in over $80 \%$ are pleased with the policy of the government and the condition of the state, and believe in even better future for the next generations (Gawlikowski, 2012b).

\section{Conclusions}

When analysing the Chinese way of changes implemented in the economy since the formation of the People's Republic of China in 1949 till the end of the first decade of the 21st century, we may assume that the way of the economic development was constantly modernized and improved by the successive generations of the government. The first of them gave to China the state united and restored after the war destruction, and introduced the real socialism economy. On the threshold of consecutive economic reforms, the program of so-called "Four Modernizations", established in January 1975 by Premier Zhou Enlai, was implemented, and concerned agriculture, industry, national defence and science and education. From today's point of view we can claim that the program was consistently implemented.

In the 1980s, China reformed the socialist economy, adding its own characteristics to those reforms. While doing it, it was guided by pragmatism, relying on the economic base, and not on the "ideological superstructure" following the principle of "searching for the truth in the facts".

In the 1990s, China realized its further development passing to the phase of the "socialist market economy", taking care of the unity of the state, with an assumption of gradual and state-controlled opening of the economy up to the world, at the same time successfully joining the globalization processes.

In the first decade of the 21st century, in addition to the further opening up to the world and a bigger and bigger share in the globalization processes, China undertook large-scale internal activities, among others related to building a "harmonious society" (Chan, 2013; Zheng \& Keat Tok, 2007). A hitherto prevailing idea of a fast increase in the significance of China on the international arena was replaced with "peaceful growth and scientific development", which clearly indicates that the way of development of the Chinese economy will be inseparably connected with scientific research into the search for modern and rational solutions (The State Council Information Office, 2005). Irrespectively, China promotes the slogan of a great renaissance of its nation, taking into consideration not only the citizens of the People's Republic of China but also the Chinese 
people all over the world.

The rationality and effectiveness of the Chinese system of planning the development, as well as the openness to new ideas and revisions of the earlier programmes and supporting the growth of the domestic production are considered as an important factor of further social and economic development of China.

We can agree with an opinion that the specific Chinese way of the social and economic development over the last 30 years is composed of, among others (Góraczyk, 2012b):

... a strong role of the state and its interventionism beside market mechanisms; authoritarianism of the government with the pressure put on the effectiveness of actions; pragmatic approach to reforms and changes; deprival of the ideological staffage; gradually staggered experimenting with reforms and new solutions; sober assessment of its own strengths and weaknesses and threats; broad opening up to the world with the strictly followed rule 'what is Chinese is essential, and what is Western or foreign-just useful. (p. 138)

\section{References}

"China" in the Common Encyclopedia of State Scientific Publishers ("Chiny" w: Encyklopedia Powszechna PWN). (1983). Warszawa: PWN.

"China" in the Great Encyclopedia of State Scientific Publishers ("Chiny" w: Wielka Encyklopedia PWN). (2001). Warszawa: PWN.

Brandt, L. (1997). Reflections on China's late 19th and the early 20th century economy. The China Quarterly, 150, $282-308$.

Chan, K. M. (2013). Harmonious Society. Retrieved from http://www.cuhk.edu.hk/centre/ccss/publications/km_chan/CKM_14.pdf

China Committee for the Promotion of International Trade. (1952). New China's economic achievements 1949-1952. Peking: Foreign Languages Press.

China from Poor Areas to Poor People, China's Evolving Poverty Reduction Agenda: An Assessment of Poverty and Inequality in China. (2009). Report No. 47349-CN, Washington: World Bank.

Chu, S. L., \& Ren, X. (2009). China's peaceful development doctrine. Seattle: The National Bureau of Asian Research.

Dahlman, C. J. (2010). Global challenges from the rapid rise of China. TMD Working Paper Series No. 041. Oxford: University of Oxford.

Dollar, D. (1998). Economic reform and allocative efficiency in China's state-owned industry. Retrieved from http://www.econ.ucla.edu/workingpapers/wp490.pdf

Flassbeck, H., Dullien, S., \& Geiger, M. (2005). China's spectacular growth since the mid-1990s-macroeconomic conditions and economic policy challenges in China in a globalizing world. New York and Geneva: UNCTAD.

$\mathrm{Fu}, \mathrm{X}$. (2012). China's role in global economic recovery. New York: Routledge.

Fung, E., \& Peng, Y. (2012). Forces driving China's economic growth in 2012: New thoughts, new strategies, new initiatives. Retrieved from http://www.kpmg.com/cn/en/IssuesAndInsights/ArticlesPublications/Documents/China-12th-Five-Year-Plan-China-EconomicGrowth-201203-2.pdf

Garnaut, R., Song, L., \& Woo, W. T. (2009). China's new place in a world in crisis: Economic, geopolitical and environmental dimensions. Canberra: Australian National University E-Press.

Gawlikowski, K. (2012a). Who is a Chinese? The history of the Chinese people (Kto jest Chińczykiem? w: Historia Chińczyków). Politics (Polityka) Special edition No. 9/2012.

Gawlikowski, K. (2012b) The People's Republic of China: Deng and the reforms. The history of the Chinese people (CHRL: Deng i reformy, w: Historia Chińczyków). Politics (Polityka) Special edition No. 9/2012.

Góralczyk, B. (2012a). The law of the party. The history of the Chinese people (Prawo partii w: Historia Chińczyków). Politics (Polityka) Special edition No. 9/2012.

Góralczyk, B. (2012b). To be like the Chinese. The history of the Chinese people (Być jak Chińczycy, w: Historia Chińczyków). Politics (Polityka) Special edition No. 9/2012.

Grotte, M., \& Życieńska, A. (2011). International monetary fund and the challenges it faces (Międzynarodowy Fundusz Walutowy i stojace przed nim wyzwania). Warsaw: National Bank of Poland. 
Kampen, T. (2000). Mao Zedong, Zhou Enlai and the evolution of the Chinese communist leadership. Copenhagen: NIAS Publishing Nordic Institute of Asian Studies.

Liberska, B. (2010). The development prospects of the Chinese economy up to 2050 year (Perspektywy rozwojowe chińskiej gospodarki do 2050 roku). Economic Studies, 4(LXVII), 331-358.

Lisbonne-de Vergeron, K. (2012). China's strengths and weaknesses. European Issues No. 234, Policy Paper, Foundation Robert Schuman.

Luttwak, E. (2012). The rise of China vs. the logic of strategy. Massachusetts: The Belknap Press of Harvard University Press.

Oziewicz, E. (2012). Made in China. The history of the Chinese people (Made in China w: Historia Chińczyków). Politics (Polityka) Special edition No 9/2012.

Qingjun, Z. (1994). Mao Zedong (1893-1976). The Quarterly Review of Comparative Education, 24(1/2), 93-106.

Shen, R. (2000). China's economic reform: An experiment in pragmatic socialism. USA: Praeger Publishers.

Szpak, J. (2007). The common history of economy (Historia gospodarcza powszechna). Warsaw: Polish Economics Publishers.

Szumski, K. (2012). The position of the dragon. The history of the Chinese people (Pozycja smoka, w: Historia Chińczyków). Politics (Polityka) Special edition No. 9/2012.

The modern China. (2012). The almanac of the most important events. The history of the Chinese people (Chiny nowożytne. Kalendarium najważniejszych wydarzeń, w: Historia Chińczyków). Politics (Polityka) Special edition No. 9/2012.

The State Council Information Office. (2005). China's peaceful development road. White Paper.

United Nations Conference on Trade and Development (UNCTAD). (2005). China in a globalizing world. New York and Geneva: UNCTAD.

World Bank. (2013). GDP growth (annual \%). Retrieved from http://data.worldbank.org/indicator/NY.GDP.MKTP.KD.ZG

Zheng, Y. N., \& Keat Tok, S. (2007). Harmonious society and harmonious world: China's policy discourse under Hu Jintao. Nottingham: China Policy Institute, the University of Nottingham. 